\title{
Removal of Copper(II) and Zinc(II) lons From Aqueous Solution by Chemical Treatment of Coal Fly Ash
}

\author{
Eleonora Sočo, ${ }^{*}$ Jan Kalembkiewicz
}

\begin{abstract}
Department of Inorganic and Analytical Chemistry, Faculty of Chemistry, Rzeszów University of Technology, 6 Powstańców Warszawy Ave., PL-959 Rzeszów, Poland
* Corresponding author's e-mail address: eleonora@prz.edu.pl
\end{abstract}

RECEIVED: April 15, $2015 *$ REVISED: August 17, 2015 * ACCEPTED: October 26, 2015

Abstract: The aim of this study was to investigate the chemical modifications of coal fly ash (CFA) treated with $\mathrm{HNO}_{3}$ or ammonium acetate $\left(\mathrm{AcNH}_{4}\right)$ or $\mathrm{NaOH}$ or sodium diethyldithiocarbamate (NaDDTC) as an adsorbent for the removal of copper(II) and zinc(II) ions from aqueous solution. The morphology of fly ash grains before and after modification was examined via X-ray diffraction (XRD) and images of scanning electron microscope (SEM). Adsorption of copper(II) and zinc(II) ions was conducted under batch process at different duration, concentrations and temperature of the suspension. Equilibrium experiments shows that the selectivity of $\mathrm{CFA-NaOH} \mathrm{nanoparticles} \mathrm{towards} \mathrm{Cu}(\mathrm{II})$ ions is greater than that of $\mathrm{Zn}(\mathrm{II})$ ions, which is related to their hydrated ionic radius and first hydrolysis equilibrium constant. The adsorption isotherms were described by Langmuir and Freundlich models. Kinetic data revealed that the adsorption fits well by the pseudo-second-order rate model with high regression coefficients. Thermodynamic parameters suggested that the immobilization $\mathrm{Cu}(\mathrm{II})$ and $\mathrm{Zn}(\mathrm{II})$ ions onto $\mathrm{CFA}-\mathrm{NaOH}$ is a spontaneous process. Results demonstrated that the treating coal fly ash with alkaline solution was a promising way to enhance $\mathrm{Cu}(I I)$ and $\mathrm{Zn}(\mathrm{II}) \mathrm{ions}$ adsorption.

Keywords: kinetic and thermodynamic adsorption, coal fly ash, copper and zinc, scanning electron microscopy, X-ray diffraction.

\section{INTRODUCTION}

OAL fly ash is particulate material produced from the coal-fired heat and power plant. The amount of coal fly ash generated in Poland was $4.2 \mathrm{Gt}$ per year, of which $52 \%(2.2 \mathrm{Gt})$ was recycled while the rest was land-filled. ${ }^{[1]}$ Fly ash is used partly in manufacturing of pozzolana cement, filler material for reclamation of low lying areas and manufacturing of bricks. ${ }^{[2,3]}$ Ash contamination poses a serious threat to environment. The confirmed presence and mobility of heavy metals from fly ash can cause significant environmental problems. ${ }^{[4-6]}$ Contamination during disposal of fly ash, as well as interaction of fly ash and heavy metals in the environment is very limited. ${ }^{[7-9]}$ The chemical composition of fly ash - abundance of amorphous aluminosilicate glass, which is the prevalent reactive phase, is what makes fly ash an important source material in zeolite synthesis. ${ }^{[10-12]}$ Hence, coal fly ash and its fly ashderived zeolite can be candidate materials for heavy metals removal..[13-18]

Adsorption is probably one of the most attractive, simple and efficient processes and consequently, the commonly used in industry, because of its simple and efficient application. ${ }^{[19-23]}$ Thus, there is a growing demand to find low-cost and efficient adsorbent for the adsorption of heavy metal ions. ${ }^{[24-28]}$

The aim of the research was uptake of $\mathrm{Cu}(\mathrm{II})$ and $\mathrm{Zn}$ (II) ions in polluted waters by chemically-modified coal fly ash. This paper will describe the equilibrium and kinetic studies which contributed to our understanding of the properties of the new adsorbent. Importantly, the effect of $\mathrm{pH}$ on the adsorption process of heavy metals by CFA and CFA-modified was explored, and the key physical and chemical characteristics of the product are described. 


\section{EXPERIMENTAL}

\section{Apparatus}

The elemental composition of the adsorbent and extracts was determined by flame atomic absorption spectrometer (FAAS, model SavantAA, GBC Scientific Equipment, Australia). Non-metal (C, N, S) determination in the coal fly ash was carried out by Elemental Analyser EA 1108 (Carlo Erba, Italy). The samples named CFA and CFA- $\mathrm{NaOH}$ were characterized by $x$-ray diffractometer (XRD) D2 Phaser (Bruker, Germany) equipped by source of $\mathrm{Cu}-\mathrm{K} \alpha$ radiation $(\lambda=$ $0.15406 \mathrm{~nm}$ ), employing scanning rate of $0.02^{\circ} \mathrm{s}^{-1}$ and $2 \Theta$ ranges from 5 to $65^{\circ}$, the operating voltage of $30 \mathrm{kV}$ and current of $10 \mathrm{~mA}$. Scanning electron microscope VEGA 3 (Tescan, USA) employing the mode of secondary electron emission at operating voltage of $20 \mathrm{kV}$, was employed for sample imaging. The characterization of coal fly ash sample was performed by infrared spectrometer (FT-IR, model Alpha, Bruker, Germany). FT-IR spectrum of the sample was recorded using $\mathrm{KBr}$ pellet method. The digestion system consist of heating unit with programmable temperature regulation ( 25 to $450^{\circ} \mathrm{C}$ ) Model DK6 (VELP Scientifica, Italy) and mineralization unit with set of reflux condensers Model TMD6 (VELP Scientifica, Italy) to modify coal fly ash. All reagents used in preparation and determination steps were of analytical and suprapure grade (Fluka, Germany and Aldrich, UK).

\section{Preparation of the Coal Fly Ash Sample}

The coal fly ash used in this study was supplied by the Rzeszów-Załęże electric power station in the south-eastern part of Poland. The studied fly ash is a residue from coal combustion using a pulverized coal firing with the furnace exit gas temperature of $1200{ }^{\circ} \mathrm{C}$. The moisture content of the fly ash was obtained by drying a $10-15 \mathrm{~g}$ sample at $105^{\circ} \mathrm{C}$ by $24 \mathrm{~h}$. After drying the sample was then placed in a desiccator for a final mass measurement. The loss on ignition (LOI) was determined by heating a pre-weighed dry sample to $600{ }^{\circ} \mathrm{C}$ over a period of $2 \mathrm{~h}$. The $\mathrm{pH}$ of the dispersed adsorbent was obtained by adding $2 \mathrm{~g}$ of coal fly ash to $100 \mathrm{~mL}$ of deionization treated water. After mixing the dispersion for $15-20 \mathrm{~min}$, its $\mathrm{pH}$ was then measured using a CPI-551 pH meter.

\section{Modification of Coal Fly Ash}

Modification of coal fly ash solution at a boiling temperature was performed following: the fly ash was treated in a $2 \mathrm{~mol} \mathrm{~L}^{-1}$ solution of $\mathrm{NaOH}$ or $1 \mathrm{~mol} \mathrm{~L}^{-1}$ solution of $\mathrm{HNO}_{3}$ or $1 \mathrm{~mol} \mathrm{~L}^{-1}$ solution of $\mathrm{AcNH}_{4}$ or $1 \mathrm{~mol} \mathrm{~L}^{-1}$ solution of NaDDTC at a solution to fly ash ratio of $10: 1$ by weight. The sample of adsorbent mass was placed into round-bottomed flask closed reflux condenser and was put solution. Suspension of fly ash was then mixed for 6 hours at $100{ }^{\circ} \mathrm{C}$.
After modification process adsorbent was decanted and was repeatedly distilled water bathed to obtain $\mathrm{pH}$ of filtrate equals $\mathrm{pH}$ of distilled water and dried in electric dryer at $105{ }^{\circ} \mathrm{C}$ temperature for 24 hours. All laboratory experiments were performed using the adsorbent as received.

\section{Adsorption of $\mathrm{Cu}(\mathrm{II})$ and $\mathrm{Zn}$ (II) lons}

The adsorption experiments of $\mathrm{Cu}(\mathrm{II})$ and $\mathrm{Zn}(\mathrm{II})$ ions onto modified coal fly ash were conducted in batch method, which permits the complete evaluation of parameters that influence the process of adsorption. In this method, a series of $100 \mathrm{~mL}$ glass flasks were filled with $50 \mathrm{~mL}$ metal ion solution of varying concentrations $\left(10-500 \mathrm{mg} \mathrm{L}^{-1}\right)$. Then $0.5 \mathrm{~g}$ of primary-CFA/modified-CFA nanoparticles was added into each flask and subjected for agitation until equilibrium is attained. The resultant solutions were centrifuged and supernatant liquids were subjected for the determination of $\mathrm{Cu}(\mathrm{II})$ and $\mathrm{Zn}(\mathrm{II})$ ions.

The metal ion concentration was analyzed by FAAS method. The concentration of metal ions remaining in the solution was calculated by taking the difference of initial and final metal ion concentrations. The content of adsorbate in coal fly ash at adsorption equilibrium $C_{s}$ (in $\mathrm{mg} \mathrm{g}^{-1}$ ) was then obtained by mass balance equation, where $C_{0}$ and $C_{a q}$ (in $\mathrm{mg} \mathrm{L}^{-1}$ ) are initial and equilibrium metal ion concentrations in solution, $V$ (in L) is the solution volume and $m$ (in $\mathrm{g})$ is the amount of dry adsorbent used.

$$
C_{s}=\frac{C_{0}-C_{a q} \cdot V_{0}}{m}=\frac{C_{a d s} \cdot V_{0}}{m}
$$

The effect of $\mathrm{pH}$ on the extent of metal ion adsorption was studied by varying the $\mathrm{pH}$ in the range $2-12$ for the metal ion concentration of $50 \mathrm{mg} \mathrm{L}^{-1}$ and all other experiments were conducted at $\mathrm{pH}=9$ unless and otherwise mentioned. The effect of $\mathrm{pH}$ on adsorption behavior was obtained by adjusting the $\mathrm{pH}$ of initial heavy metals solution to desired $\mathrm{pH}$, using either $0.1 \mathrm{~mol} \mathrm{~L}^{-1} \mathrm{NaOH}$ or $0.1 \mathrm{~mol} \mathrm{~L}^{-1}$ $\mathrm{HNO}_{3}$ solution.

The adsorption kinetic experiments were conducted at room temperature using the $0.5 \mathrm{~g}$ of dry CFA and $50 \mathrm{~mL}$ metal ion solution having a concentrations of $50 \mathrm{mg} \mathrm{L}^{-1}$ (using A.R. Grade salts), and mixed at $180 \mathrm{rpm}$, using an ELPINPLUS mixer. The rate of heavy metals uptake was then measured by taking samples at various time intervals for five hours.

The effect of temperature on the degree of adsorption of metal ions on CFA was also evaluated for the above said concentration of metal ion. The rate of uptake was determined at 293, 308, 318 and $333 \mathrm{~K}$ using deionized water that was adjusted to $\mathrm{pH}=9$. The adsorption set was constructed to allow the continuous measurement of $\mathrm{pH}$ during phase mixing of thermostatic system. 


\section{RESULTS AND DISCUSSION \\ Physical and Chemical Properties of Coal Fly Ash}

Composition and characteristic of coal fly ash are shown in Table 1. The major components of all fly ashes were oxides of Si and Al, and various other oxides.

Scanning electron microscopy (SEM) was employed to analyse the elemental composition of coal fly ash before and after treating with $\mathrm{NaOH}$ (Figure 1).

The untreated fly ash (CFA) and $\mathrm{NaOH}$-treated fly ash (CFA-NaOH) had similar elements. XRD patterns of the samples were presented in Figure 2. The XRD pattern of the CFA showed the presences of quartz, mullite, magnetite and hematite (Figure 2a), after alkaline treatment, the amounts of mineral in the CFA- $\mathrm{NaOH}$ were decreased from the CFA, as was observed in the reduction of these peak intensities (Figure 2b). We also observed the appearance of zeolites, which were $\mathrm{NaX}$ and sodalite.

This observation indicated the conversion of fly ash into zeolite-like material under alkaline condition. Previous studies also reported a similar observation.[29] SEM observation of the CFA showed the presence of microparticles in the shape of smooth balls (microspheres) (Figure 3a). After treating with $\mathrm{NaOH}$, the ball-shaped particles of CFA were partly transformed into smooth surface and agglomerations of various shapes with observation of crystal formation, e.g. plates and rods (Figure $3 b$ ).

The particle surface of CFA- $\mathrm{NaOH}$ showed the transformation of fly ash into zeolite-like structure, as was confirmed by the XRD data of this study (Figure 2b) and was also observed by other studies. ${ }^{[16,29]}$
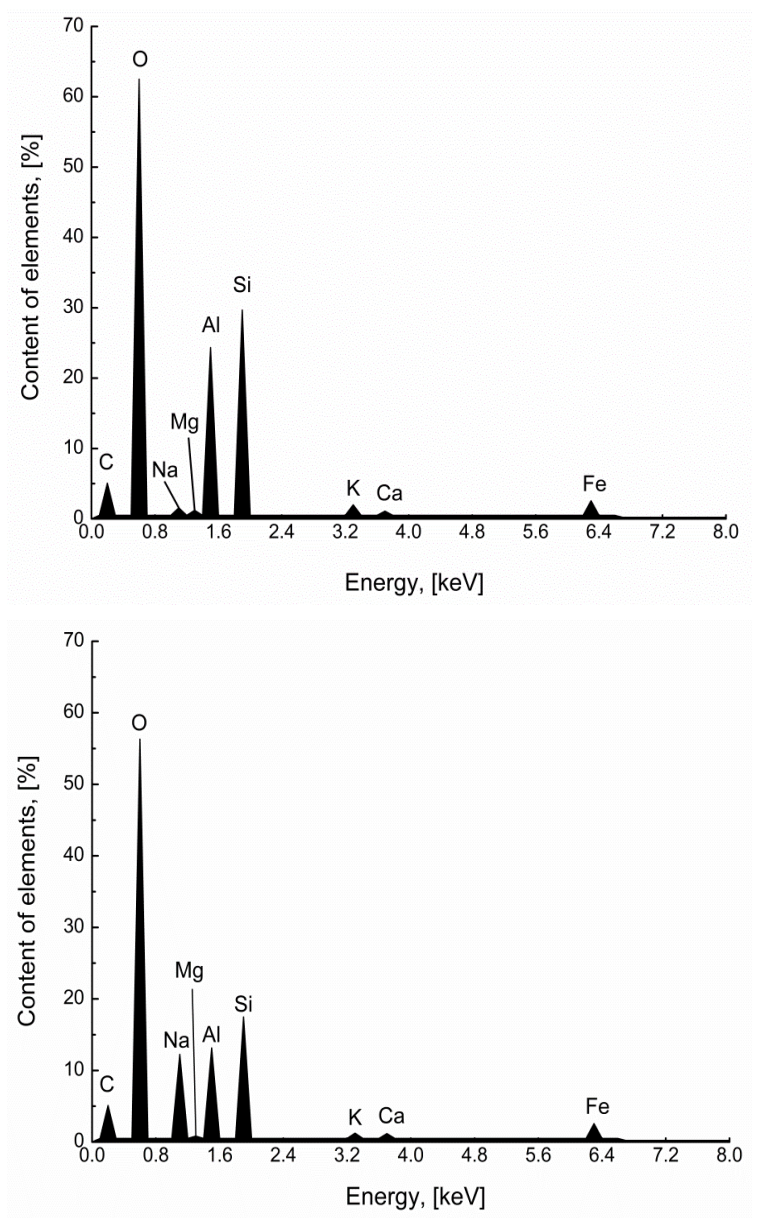

Figure 1. SEM-EDS pattern of coal fly ash before and after treating with $\mathrm{NaOH}$. a) the untreated CFA, and b) the $\mathrm{NaOH}$ treated CFA.

Table 1. Physical properties of the coal fly ash.

\begin{tabular}{|c|c|c|c|}
\hline Determination & Value & Determination & Value \\
\hline $\mathrm{pH}$ & 8.3 & \multicolumn{2}{|l|}{ Content of nonmetals / \% (mass fraction) } \\
\hline \multirow{2}{*}{$\mathrm{pH}_{\mathrm{PZC}}$} & \multirow{2}{*}{7.7} & carbon & 5.76 \\
\hline & & - $\quad$ nitrogen & 0.00 \\
\hline Bulk density, $\rho / \mathrm{kg} \mathrm{m}^{-3}$ & 620 & sulfur & 0.00 \\
\hline Moisture content / \% (mass fraction) & 1.08 & \multicolumn{2}{|l|}{ Content of metals oxide / \% (mass fraction) } \\
\hline & & $\mathrm{SiO}_{2}$ & 50.3 \\
\hline Loss on Ignitıon (LOI) / \% (mass fraction) & 1.50 & $\mathrm{Al}_{2} \mathrm{O}_{3}$ & 32.6 \\
\hline Content of combustible part / \% (mass fraction) & 9.9 & $\mathrm{Fe}_{2} \mathrm{O}_{3}$ & 5.13 \\
\hline & & $\mathrm{K}_{2} \mathrm{O}$ & 2.79 \\
\hline Specific surface area $/ \mathrm{m}^{2} \mathrm{~g}^{-1}$ & 39.3 & $\mathrm{MgO}$ & 1.46 \\
\hline \multirow{2}{*}{ Total pore volume $/ \mathrm{cm}^{3} \mathrm{~g}^{-1}$} & \multirow{2}{*}{0.171} & $-\quad \mathrm{CaO}$ & 1.30 \\
\hline & & $-\quad \mathrm{Na}_{2} \mathrm{O}$ & 0.56 \\
\hline Average particle size / $\AA$ & 28.7 & $\mathrm{SiO}_{2} / \mathrm{Al}_{2} \mathrm{O}_{3}$ & 1.54 \\
\hline
\end{tabular}



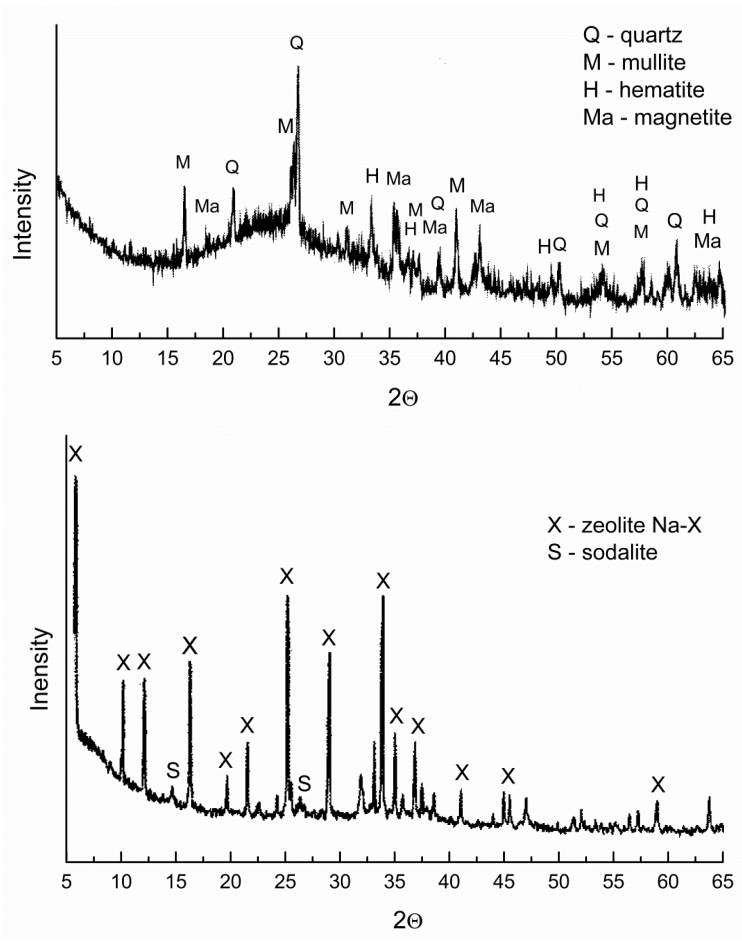

Figure 2. XRD patterns of a) the untreated CFA and $b$ ) the $\mathrm{NaOH}$ treated CFA.

\section{The Point of Zero Charge Determination}

The point of zero charge (PZC) was determined using the solid addition method. Suspensions of $1 \mathrm{~g}$ of fly ash mass were put into contact with $50 \mathrm{~mL}$ of $0.1 \mathrm{M} \mathrm{KNO}_{3}$ solutions adjusted at different $\mathrm{pH}$ values. The $\mathrm{pH}_{0}$ was adjusted using

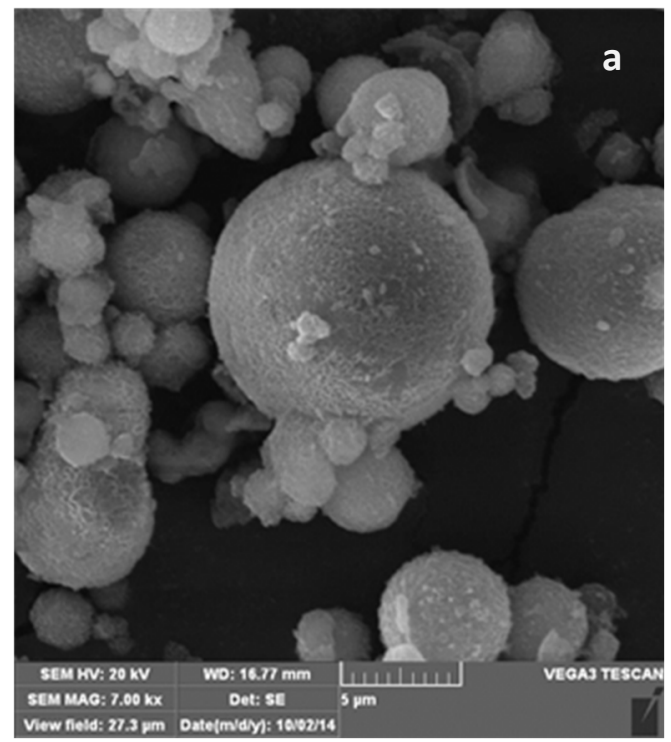

a pH meter to $2,3,4,5,6,7,8,9,10$ and 11 ( $\pm 0.1 \mathrm{pH}$ units) with $0.1 \mathrm{M} \mathrm{HNO}_{3}$ and $0.1 \mathrm{M} \mathrm{NaOH}$. The suspensions were agitated for $24 \mathrm{~h}$ in a shaker at $180 \mathrm{rpm}$ until an equilibrium $\mathrm{pH}$ value was reached. After this time each resulting final $\mathrm{pH}\left(\mathrm{pH}_{\mathrm{f}}\right)$ was measured and the initial $\mathrm{pH}\left(\mathrm{pH}_{0}\right) v s$. the difference between the final and initial $\mathrm{pH}$ values $\left(\mathrm{pH}=\mathrm{pH}_{\mathrm{f}}\right.$ $\mathrm{pH}_{0}$ ) was plotted. The PZC was taken as the point where $\Delta \mathrm{pH}=0$. The point of intersection of the resulting curve at which $\mathrm{pH}_{0}$ gave the $\mathrm{PZC}$ (Figure 4).

\section{Spectroscopic Measurements (FT-IR)}

Based on the spectrum obtained from the Fourier transform infrared, FT-IR, analysis of the coal fly ash as presented in Figure 5. In coal fly ash was observed absorption broadband in the range of $3400 \mathrm{~cm}^{-1}$, band in range of 1600 $\mathrm{cm}^{-1}$ and absorption broadband at about $1100 \mathrm{~cm}^{-1}$. Band at $3400 \mathrm{~cm}^{-1}$ appropriate of stretching vibrations $\mathrm{v}_{\mathrm{O}-\mathrm{H}}$. This indicates the presence of both free and hydrogen bonded $\mathrm{OH}$ groups on the adsorbent surface.

The spectrum was in air atmosphere recorded that's why clear-cut interpretation this band was difficulty because it could derive from-OH groups, chemically bounded with surface of fly ash, and also from stretching vibrations $\mathrm{H}-\mathrm{O}-\mathrm{H}$ of water molecule adsorbed (peak at $3400 \mathrm{~cm}^{-1}$ ) on ash surface. The stretching of the $\mathrm{OH}$ groups bound to methyl radicals presented a very weak signal $\sim 2900 \mathrm{~cm}^{-1}$ for CFA. Interpretation of next band $\left(1600 \mathrm{~cm}^{-1}\right)$, for the sake of structure complexity is not clear but it was fund that band was from oxide compounds of fly ash derived.

These compounds influence on symmetry of condensed aromatic rings system, therefore $\mathrm{C}=\mathrm{C}$ bond is active bond in infrared, shows absorbance in the field of

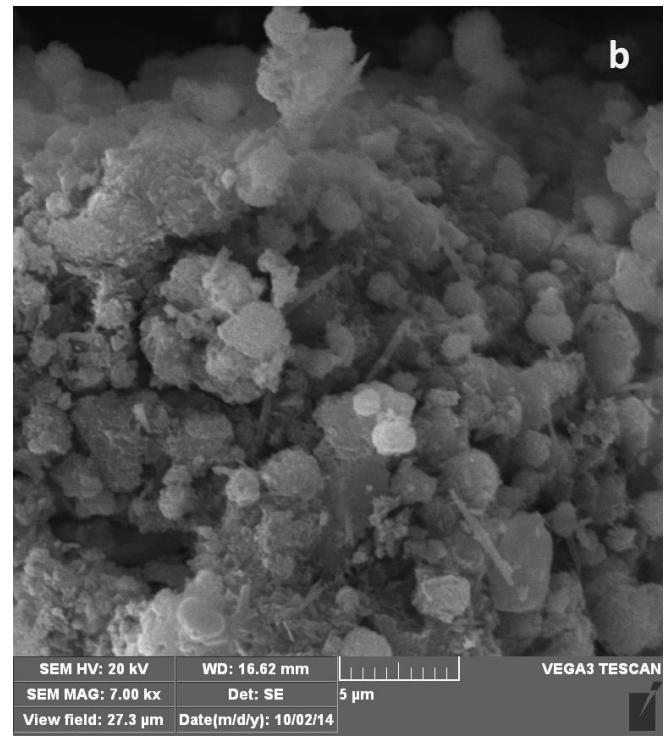

Figure 3. SEM images of the coal fly ash; a) the untreated CFA and b) the CFA after treating with $\mathrm{NaOH}$. 


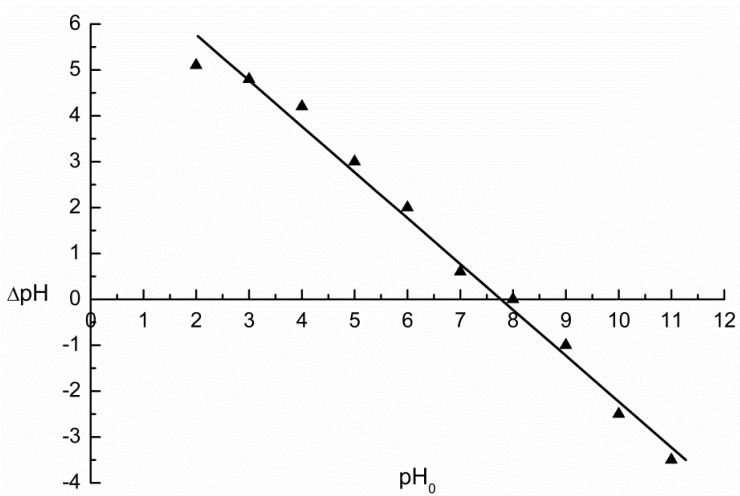

Figure 4. Point of zero charge of the coal fly ash.

$1600 \mathrm{~cm}^{-1}$. The IR spectra of the adsorbent indicated weak and broad peaks in the region of $1600-1800 \mathrm{~cm}^{-1}$ corresponding to $\mathrm{CO}$ group stretching from aldehydes and ke tones. The band at $1600 \mathrm{~cm}^{-1}$ may be due to conjugated hydrocarbon bonded carbonyl groups. The $1360-1420 \mathrm{~cm}^{-1}$ band in CFA may be attributed to the aromatic $\mathrm{CH}$ and carboxyl-carbonate structures. The most intensity of band in spectrum of coal fly ash is in the field of $1100 \mathrm{~cm}^{-1}$ can be described of stretching vibrations of bounds in $\mathrm{C}-\mathrm{O}\left(\mathrm{v}_{\mathrm{C}-\mathrm{O}}\right)$ carboxylic, phenolic, etheral groups. The FT-IR spectra showed transmittance at $1100 \mathrm{~cm}^{-1}$ due to the vibration of the $\mathrm{CO}$ group in lactones.

Moreover, asymmetrical stretching of $\mathrm{SiO}_{4}{ }^{4-}$ or $\mathrm{AlO}_{4}{ }^{5-}$ band (broad-strong) is corresponding to the variation in frequency from 1100 to $1010 \mathrm{~cm}^{-1}$. The double ring of secondary building unit (SBU) is observed to be present in the zeolite structure in the CFA, corresponding to infrared frequency, equal to $570 \mathrm{~cm}^{-1}$. Based on the FT-IR spectrum, it can be observed that there is presence of pore openings corresponding to frequency range from 450 to $400 \mathrm{~cm}^{-1}$ in the CFA which can be attributed to the dissolution of the minerals (viz., quartz and mullite) present in the fly ash ${ }^{30}$. The surface functional groups from IR spectra, the broad bands provide information about the nature of the surface oxides. The presence of polar groups on the surface is likely to give considerable cation exchange capacity to the adsorbents. The surface structures of carbon-oxygen (functional groups) are by far the most important structures in influencing the surface characteristics and surface behaviour of coal fly ash.

\section{Effect of $\mathrm{pH}$}

One of the most important factors that affect the adsorption of metal ions is the $\mathrm{pH}$ of the solution. The $\mathrm{pH}$ affects both the adsorbent and adsorbate chemistry in solution. The effect of $\mathrm{pH}$ on the adsorption of $\mathrm{Cu}(\mathrm{II})$ and $\mathrm{Zn}(\mathrm{II})$ ions onto CFA was studied at $\mathrm{pH} 2-11$ for initial metal ion concentration of $50 \mathrm{mg} \mathrm{L}^{-1}$. It was observed from Figure 6 that

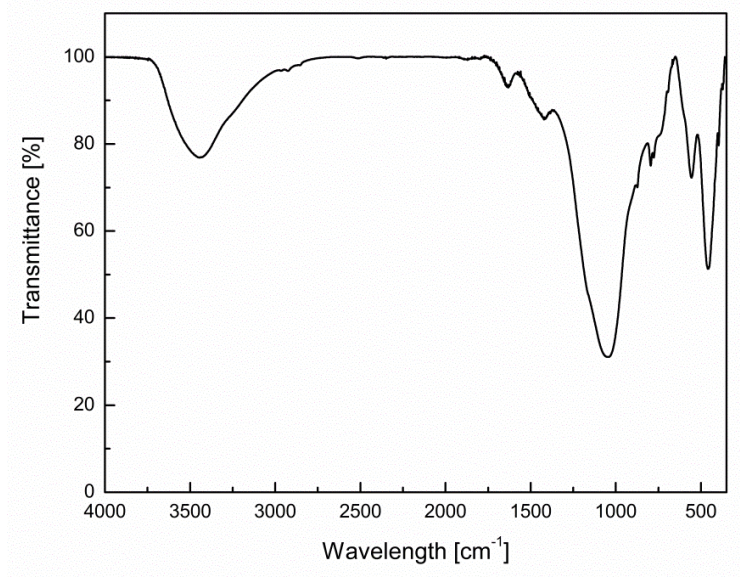

Figure 5. FT-IR spectrum of coal fly ash.

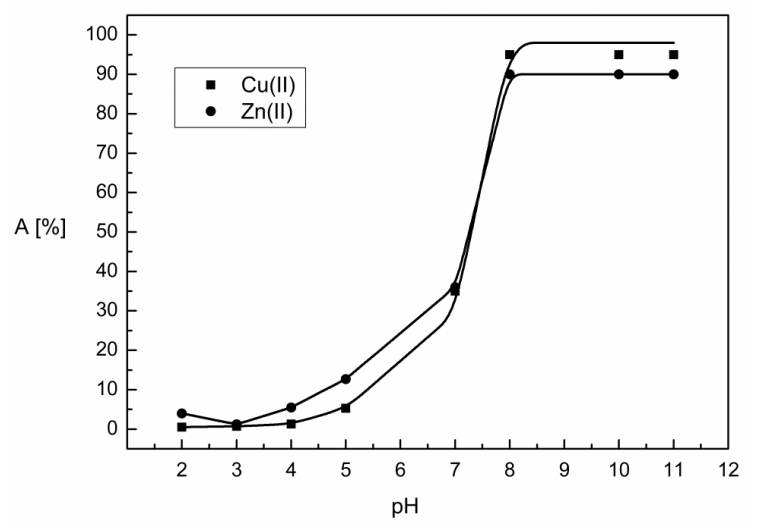

Figure 6. Effect of solution $\mathrm{pH}$ on the percentage adsorption of $\mathrm{Cu}(\mathrm{II})$ and $\mathrm{Zn}(\mathrm{II})$ ions by FA.

the percentage of adsorption of metal ions increased with increase in the solution $\mathrm{pH}$ for two metal ions studied.

The effect of solution $\mathrm{pH}$ on adsorption could be explained by considering the surface charge of the CFA and degree of speciation of sorbents. Understanding the sorption of metal ions from aqueous solution on oxides requires knowledge of chemistry of the oxide/water interface. At acidic $\mathrm{pH}$ the adsorbent surface, hydrous oxide $(\mathrm{MOH})$ surface will be completely covered by $\mathrm{H}^{+}$ions $\left(\mathrm{MOH}+\mathrm{H}^{+} \rightarrow\right.$ $\mathrm{MOH}_{2}{ }^{+}$). At alkaline $\mathrm{pH}$, hydroxide ions react with the hydrous oxide to produce deprotonated $\left(\mathrm{MOH}+\mathrm{OH}^{-} \rightarrow \mathrm{MO}^{-}\right.$ $+\mathrm{H}_{2} \mathrm{O}$ ). It is well known that both zinc and copper appears predominantly as $\mathrm{Cu}^{2+}$ and $\mathrm{Zn}^{2+}$ at $\mathrm{pH}<5$. As both the metal ions exists as $\mathrm{Cu}^{2+}$ and $\mathrm{Zn}^{2+}$ at low $\mathrm{pH}$, there will be competition between $\mathrm{H}^{+}$ions for the surface sites and an electrostatic repulsion between positively charged adsorbent and adsorbate. At a lower $\mathrm{pH}$, the oxide surface will have positive character and there exists a competition between $\mathrm{H}^{+}$ ions and $M(I I)$ ions for the active surface sites and hence, 
lesser adsorption was observed. With increase in the $\mathrm{pH}$ from 5 to 7 (at moderate $\mathrm{pH}$ ) the surface deprotonation of CFA occurs and leads to the electrostatic attraction between the positively charged metal ions and the partially negatively charged adsorbent surface which in turn increases the percentage of adsorption. The increase in the adsorption of $\mathrm{Cu}(\mathrm{II})$ and $\mathrm{Zn}$ (II) on CFA with increase in the solution $\mathrm{pH}$ is also explicable on the basis of increased dissociation of surface hydroxyl groups from the surface of CFA and the subsequent formation of metal ions species such as $\mathrm{ZnOH}^{+}, \mathrm{Zn}(\mathrm{OH})_{2}, \mathrm{CuOH}^{+}, \mathrm{Cu}_{2}(\mathrm{OH})_{2}{ }^{2+}$ and $\mathrm{Cu}(\mathrm{OH})_{2}$, at $\mathrm{pH} 7-10$ of low solubility may contribute in part to maximum percentage removal of metal ions or $\left(\mathrm{Cu}(\mathrm{OH})_{2}\right.$, $\mathrm{Cu}(\mathrm{OH})_{3}{ }^{-} \mathrm{Cu}(\mathrm{OH})_{4}{ }^{2-}, \mathrm{Zn}(\mathrm{OH})_{2}, \mathrm{Zn}(\mathrm{OH})_{3}{ }^{-}$and $\mathrm{Zn}(\mathrm{OH})_{4}{ }^{2-}$ ) at $\mathrm{pH}>10$ (Figures 7 and 8).

It is well known that zinc and copper hydroxide has amphoteric properties. Thus it appears that as soon as the precipitation begins, adsorption process occurring at the CFA surface is overshadowed. Hence the adsorption observed at $\mathrm{pH} 7-10$ is due to the combined process of adsorption $\left(\mathrm{CuOH}^{+}, \mathrm{Cu}_{2}(\mathrm{OH})_{2}{ }^{2+}, \mathrm{ZnOH}^{+}\right)$and precipitation $\left(\mathrm{Cu}(\mathrm{OH})_{2}, \mathrm{Zn}(\mathrm{OH})_{2}\right)$ of metal ions or at $\mathrm{pH}>10$ is also due to the combined process of precipitation $\left(\mathrm{Cu}(\mathrm{OH})_{2}, \mathrm{Zn}(\mathrm{OH})_{2}\right)$ and adsorption $\left(\mathrm{Cu}(\mathrm{OH})_{3}{ }^{-}, \mathrm{Cu}(\mathrm{OH})_{4}{ }^{2-}, \mathrm{Zn}(\mathrm{OH})_{3}{ }^{-}, \mathrm{Zn}(\mathrm{OH})_{4}{ }^{2-}\right)$ of metal ions. It can be seen from the figure that, in case of $\mathrm{Cu}(\mathrm{II})$ ions after reaching the maximum the percentage adsorption decreases, this trend is attributed to the solubility of formed $\mathrm{Cu}(\mathrm{OH})_{2}, \mathrm{Cu}(\mathrm{OH})_{3}{ }^{-}$and $\mathrm{Cu}(\mathrm{OH})_{4}{ }^{2-}$ at higher $\mathrm{pH}$. At lower $\mathrm{pH}<3.0$, the dissolution of CFA may occur and hence, the optimum $\mathrm{pH}$ of 9 was selected for the adsorption of $\mathrm{Cu}$ (II) and $\mathrm{Zn}$ (II) onto CFA. The equilibrium adsorption capacity of CFA changed very little within the $\mathrm{pH}$ range of 5-7 (Figure 6) and decreased in solutions with lower $\mathrm{pH}$ values. At $\mathrm{pH}=2, \mathrm{C}_{\infty}$ was reduced by $30 \%$, compared with the value at $\mathrm{pH}=7$.

The heavy metal sorption is attributed to different mechanisms of ion-exchange processes as well as to the adsorption process. During the possible ion exchange process, in the beginning, metal ions may move through either the pores of CFA mass. Secondly, they may replace exchangeable cations, mainly surface hydroxyl groups. The replacement of the surface hydroxyl groups of CFA was supported by the experimental results.

It was observed that after the equilibration, the measured $\mathrm{pH}$ was lesser when compared to that of initial $\mathrm{pH}$ of the solution and hence it was concluded that the adsorption of $\mathrm{Cu}$ (II) and $\mathrm{Zn}$ (II) onto CFA was ion exchange reaction between the metal cations and surface protons.

\section{Kinetics of Heavy Metal Ions Adsorption}

The influence of contact time on the amount of metal ion remains in the solution after adsorption by CFA was studied

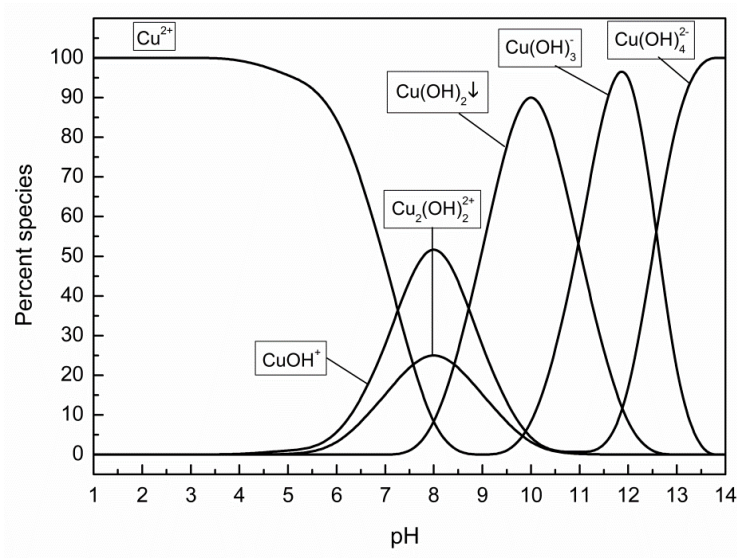

Figure 7. Distribution of the prevalent species of copper in aqueous solution as a function of $\mathrm{pH}$. The calculations were carried out using Minteq ver. 3.0.

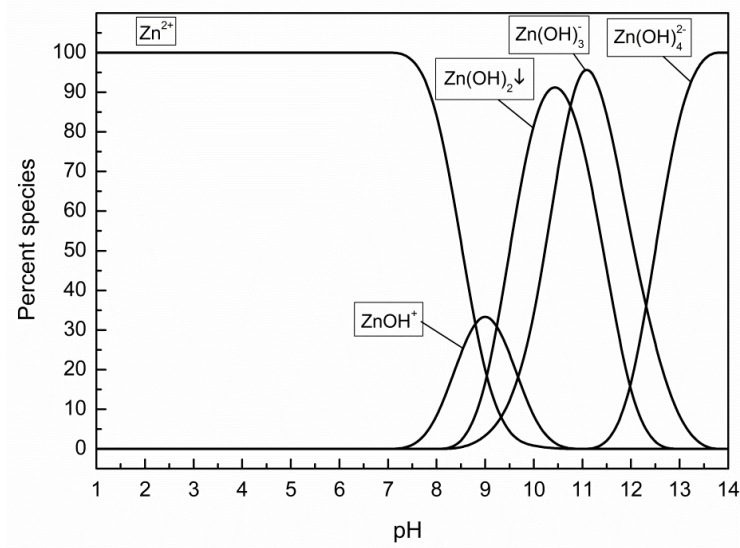

Figure 8. Distribution of the prevalent species of zinc in aqueous solution as a function of $\mathrm{pH}$. The calculations were carried out using Minteq ver. 3.0.

in the solution containing $50 \mathrm{mg} \mathrm{L}^{-1}$ of $\mathrm{Cu}(\mathrm{II})$ and $\mathrm{Zn}$ (II) ions in the range of 15 minutes - 5 hours at room temperature $\left(20 \pm 2{ }^{\circ} \mathrm{C}\right)$. It can be seen from Figure 9 , that the amount of $\mathrm{Cu}(\mathrm{II})$ and $\mathrm{Zn}(\mathrm{II})$ ion remaining in the solution after adsorption by CFA decreased sharply with contact time until the equilibrium was attained.

That is the process of adsorption increased with increase in contact time until the establishment of equilibrium between the metal ions adsorbed on the surface of CFA and those present in the solution. After it reached the equilibrium, there were no significance changes in metal ion concentrations. The adsorption took place more rapidly at initial stages and gradually slowed down as it reaches the equilibrium state. This behavior is quite common due to the saturation of the available surface active sites. The experiments revealed that the equilibrium was reached within 2 hours for both the metal ions, after that saturation could be 


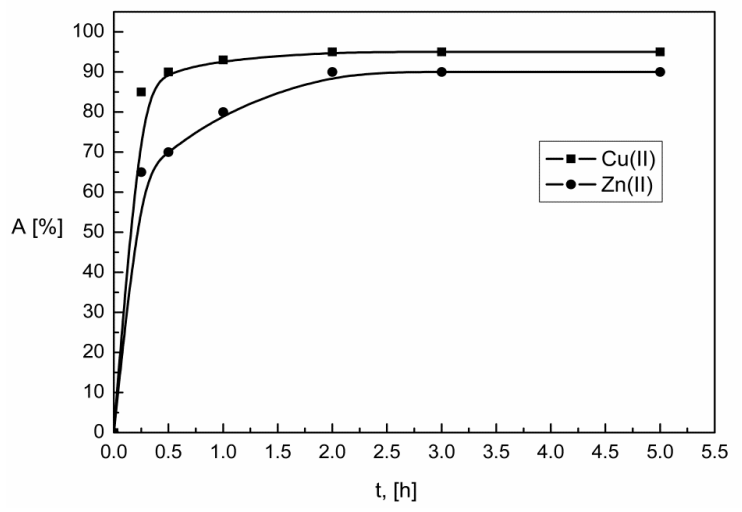

Figure 9. Mixing time dependence on $\mathrm{CU}(\mathrm{II})$ and $\mathrm{Zn}(\mathrm{II})$ ions adsorption $(A)$ on $F A$

expected to occur. However, as can be seen from figure, the rate of adsorption of $\mathrm{Cu}(\mathrm{II})$ onto CFA surface was faster than $\mathrm{Zn}(\mathrm{II})$ ions.

In order to evaluate the kinetic mechanism for the adsorption of $\mathrm{Cu}(\mathrm{II})$ and $\mathrm{Zn}$ (II) ions on CFA, pseudo-first-order, pseudo-second-order, and intra-particle diffusion models were employed. A good correlation of the kinetic data explains the adsorption mechanism of the metal ions on the solid phase.

\section{Kinetic modeling}

In order to investigate the mechanism and to determine the rate controlling step of adsorption of $\mathrm{Cu}(\mathrm{II})$ and $\mathrm{Zn}$ (II) ions kinetic models were used. The rate constants were calculated by using pseudo-first-order and pseudo-second-order kinetic models and the rate controlling step was determined by intra-particle diffusion model.

\section{PSEUDO-FIRST-ORDER RATE MODEL}

Pseudo-first-order model generally expressed as follows:

$$
\begin{aligned}
& C_{a d s}=C_{0}\left(1-e^{-k_{1} t}\right) \\
& \ln \left(C_{0}-C_{a d s}\right)=-k_{1} t+\ln C_{0} \\
& \ln \frac{C_{0}}{C_{0}-C_{a d s}}=k_{1} t
\end{aligned}
$$

The values of $k_{1}$ was calculated from the slope of the linear plot of $\ln \left(C_{0}-C_{a d s}\right)$ versus $t$.

\section{PSEUDO-SECOND-ORDER RATE MODEL}

The values of rate constant $k_{2}$ can be determined from the plot of $\frac{1}{C_{0}-C_{o d s}}$ versus $t$ by using following formula:

$$
\frac{1}{C_{0}-C_{a d s}}=k_{2} t+\frac{1}{C_{0}}
$$

furthermore, the rate of adsorption can also be calculated

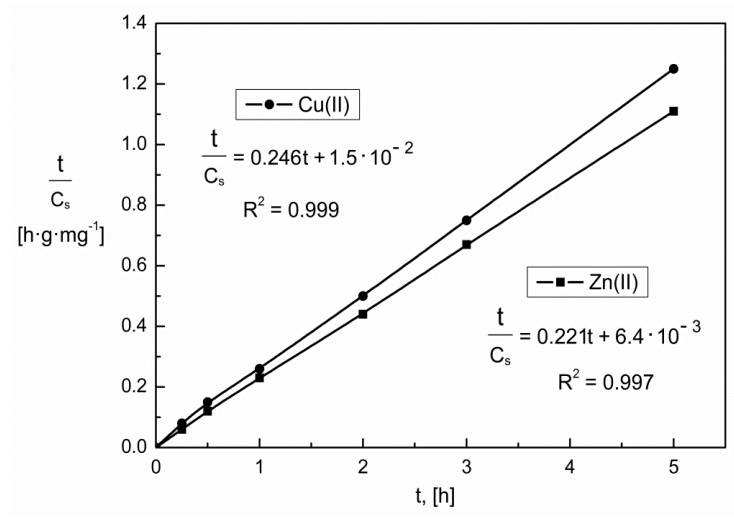

Figure 10. Intra-particle diffusion model of $\mathrm{Cu}(\mathrm{II})$ and $\mathrm{Zn}(\mathrm{II})$ ions adsorption by FA.

by using following formula:

$$
\frac{t}{C_{a d s}}=\frac{1}{C_{0}} t+\frac{1}{k_{2} C_{0}^{2}}
$$

Slope of the $t / C_{\text {ads }}$ versus $t$ plot was then used to obtain the rate constant $k_{2}$ (Figure 10). The correlation coefficients, shown in Table 2, together with the calculated kinetic data (Figure 10), indicated that [Eq. (6)] fitted the experimental data.

The values of correlation coefficients $R^{2}$ of pseudofirst-order model were slightly lesser than pseudo-secondorder model indicating that the pseudo-second-order model is better obeyed than pseudo-first-order model. As a part of the kinetic data analysis, it is essential to assess whether the observed data were affected by the diffusion of the metal ions into the pore structure of the adsorbent.

The initial adsorption rate $\alpha$ [Eq. (7)], when $t \rightarrow 0$, can be calculated by using following formula:

$$
\alpha=k_{2} C_{0}^{2}
$$

The initial rate of adsorption calculated from pseudosecond-order rate equation for $\mathrm{CU}$ (II) and $\mathrm{Zn}$ (II) were 375 and $160 \mathrm{mg} \mathrm{g}^{-1} \mathrm{~h}^{-1}$ respectively, indicating the higher adsorption rate of $\mathrm{CU}$ (II) compared to $\mathrm{Zn}$ (II) ion on CFA.

\section{INTRA-PARTICLE DIFFUSION MODEL}

The overall reaction kinetics for the adsorption of $\mathrm{Cu}(\mathrm{II})$ and $\mathrm{Zn}$ (II) is a pseudo-second-order process. However, this could not highlight on the rate-limiting step. The rate-limiting step (slowest step of the reaction) may be either the boundary layer (film) or the intra-particle (pore) diffusion of solute on the solid surface from bulk of the solution in a batch process.

The model is given as follows:

$$
C_{s}=k_{i} t^{1 / 2}+b
$$

where $C_{s} / \mathrm{mg} \mathrm{g}^{-1}$ is the adsorption capacity at any time $t$ 
and $k_{i} / \mathrm{mg} \mathrm{g}^{-1} \mathrm{~h}^{-1 / 2}$ is the intra-particle diffusion rate constant and $b / \mathrm{mg} \mathrm{g}^{-1}$ is the film thickness. Greater the value of $b$ greater will be the effect of boundary layer on adsorption process. If the rate limiting step be the intra-particle diffusion, the plot of $C_{a d s}$ against the square root of time should be a straight line and pass through the origin with $b=0$. The deviation of the plot from the linearity clearly indicates the rate-limiting step should be boundary layer (film) diffusion controlled.

Multi linear plots of $C_{a d s}$ versus $t^{1 / 2}$ are presented in Figure 11. Sharp first linear portion is due to the boundary layer (film) diffusion and the second linear one is for the pore diffusion. ${ }^{[31]}$ Non-linearity of the plots had indicated the multi stage adsorption of $\mathrm{Cu}$ (II) and $\mathrm{Zn}$ (II) by CFA. Extrapolation of the linear portions of the first plots back to the $y$-axis gave the intercept equal to the boundary layer thickness or film thickness.

It can be seen from Figure 11 that the plots possess multi-linear portions; it indicates that the two or more steps influence the sorption process. The initial portion in the plots has attributed to the boundary layer effect or external mass transfer effect. The slope and intercept of the first portion of the plots has indicated the boundary layer (film) diffusion characteristics of the adsorption while that of the second linear portion is for the pore diffusion.

The values for $k_{i 1}$ and $k_{i 2}$ were computed from the slope of each plot. Table 2 gives the values of these parameters $\left(k_{i 1}, k_{i 2}\right.$ and $\left.b\right)$. The values of $k_{i 1}$ were about hundred times greater than that of $k_{i 2}$, and suggested that the boundary layer (film) diffusion had controlled the process of adsorption in the present case. The $b$ value for $\mathrm{Cu}(\mathrm{II})$ is greater than that of $\mathrm{Zn}$ (II) ions, which indicates the greater effect of boundary layer on the adsorption process of $\mathrm{CU}(\mathrm{II})$.

The Elovich equation, which applies to heterogeneous surfaces, ${ }^{[32]}$ was also applied in an effort to better describe the chemisorption process. It is generally expressed as:

$$
C_{s}=\frac{1}{b} \ln t+\frac{1}{b} \ln \alpha B
$$

where, $\alpha$ is the initial adsorption rate (in $\mathrm{mg} \mathrm{g}^{-1} \mathrm{~h}^{-1}$ ) and 8 is related to the extent of surface coverage and the activation energy for chemisorption (in $\mathrm{g}^{-1} \mathrm{mg}$ ). A plot of $C s$ versus Int gives a linear trace with a slope of $\frac{1}{b}$ and an intercept of $\frac{1}{b} \ln \alpha \beta$. Linear plots with reasonable $R^{2}$ values indicate agreement with chemisorption processes contributing significantly to adsorption rates. However, experimental data again showed better agreement with the pseudo-secondorder kinetic model (Table 2).

\section{ADSORPTION ISOTHERM MODELING}

Isotherms are the equilibrium relations between the concentration of adsorbate on the solid phase and its concentration in the liquid phase. From the isotherms the

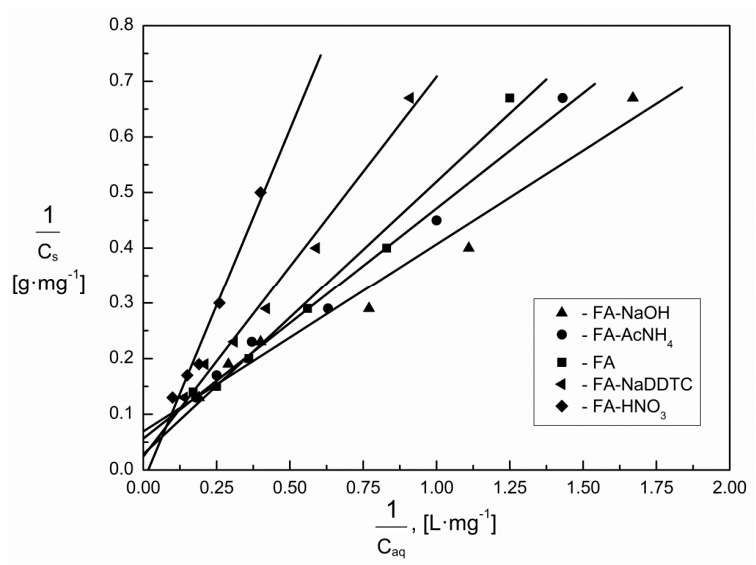

Figure 11. Intra-particle diffusion model of $\mathrm{Cu}(\mathrm{II})$ and $\mathrm{Zn}(\mathrm{II})$ ions adsorption by FA.

Table 2. Kinetic model constants and correlation coefficients for the adsorption systems in the study.

\begin{tabular}{cccc}
\hline Model & Parameter & $\mathrm{Cu}(\mathrm{II})$ & $\mathrm{Zn}(\mathrm{II})$ \\
\hline $\begin{array}{c}\text { Pseudo-first-order } \\
\text { model }\end{array}$ & $R^{2}$ & 0.61 & 0.45 \\
\hline $\begin{array}{c}\text { Pseudo-second- } \\
\text { order model }\end{array}$ & $\mathrm{R}^{2}$ & 0.999 & 0.997 \\
\hline $\mathrm{g} \mathrm{mg}^{-1} \mathrm{~h}^{-1}$ & 15.0 & 6.4 \\
\hline Intra-particle & $R^{2}$ & 0.999 & 0.998 \\
diffusion model & $k_{1} / \mathrm{mg} \mathrm{g}^{-1} \mathrm{~h}^{-1 / 2}$ & 0.60 & 1.61 \\
\cline { 2 - 4 } & $b / \mathrm{mg} \mathrm{g}^{-1}$ & 3.7 & 2.2 \\
\hline & $R^{2}$ & 0.984 & 0.941 \\
& $10^{2} \mathrm{k}_{2} / \mathrm{mg} \mathrm{g}^{-1} \mathrm{~h}^{-1 / 2}$ & 2.3 & 5.8 \\
\hline Elovich model & $R^{2}$ & 0.907 & 0,915 \\
& $\alpha / \mathrm{mg} \mathrm{g}^{-1} \mathrm{~h}^{-1}$ & 375 & 160 \\
& $\beta / \mathrm{g}^{-1} \mathrm{mg}^{2}$ & 0.31 & 0.18 \\
\hline
\end{tabular}

maximum adsorption capacity can be obtained. These data provide information on the capacity of the sorbent or the amount required to remove a unit mass of pollutant under the system conditions. Data has been subjected to different adsorption isotherms. Langmuir and Freundlich models are the most common isotherms describing solid-liquid adsorption system.

\section{LANGMUIR ISOTHERM}

Langmuir isotherm is often used to describe adsorption of solute from liquid solutions and this model assumes monolayer adsorption onto a homogeneous surface with finite number of identical sites and expressed by the following equation:

$$
\begin{aligned}
& C_{s}=C_{\infty} \frac{K_{L} C_{a q}}{1+K_{L} C_{a q}} \\
& \frac{1}{C_{s}}=\frac{1}{K_{L} C_{\infty}} \cdot \frac{1}{C_{a q}}+\frac{1}{C_{\infty}}
\end{aligned}
$$


Table 3. The values of Freundlich and Langmuir adsorption parameters for $\mathrm{Cu}(\mathrm{II})$ ion.

\begin{tabular}{|c|c|c|c|c|c|c|c|}
\hline \multirow{2}{*}{ modification } & \multicolumn{4}{|c|}{ Freundlich constants } & \multicolumn{3}{|c|}{ Langmuir constants } \\
\hline & $K_{\mathrm{F}} / \mathrm{L} \mathrm{mg}^{-1}$ & $1 / n$ & $n$ & $R^{2}$ & $K_{\mathrm{F}} / \mathrm{L} \mathrm{mg}^{-1}$ & $\mathrm{C} / \mathrm{mg} \mathrm{g}^{-1}$ & $R^{2}$ \\
\hline $\mathrm{NaOH}$ & $7.4 \times 10^{-3}$ & 0.90 & 1.11 & 0.936 & $2.0 \times 10^{-3}$ & 15.2 & 0.995 \\
\hline $\mathrm{AcNH}_{4}$ & $3.4 \times 10^{-3}$ & 0.63 & 1.59 & 0.983 & $1.5 \times 10^{-3}$ & 10.3 & 0.988 \\
\hline primary FA & $1.3 \times 10^{-3}$ & 0.76 & 1.32 & 0.985 & $1.0 \times 10^{-3}$ & 7.5 & 0.993 \\
\hline NaDDTC & $1.9 \times 10^{-3}$ & 0.80 & 1.25 & 0.979 & $1.1 \times 10^{-3}$ & 4.7 & 0.998 \\
\hline $\mathrm{HNO}_{3}$ & $1.5 \times 10^{-3}$ & 0.86 & 1.16 & 0.968 & $1.0 \times 10^{-3}$ & 3.0 & 0.975 \\
\hline
\end{tabular}

Characteristic constants of Langmuir equation; $K_{L}$ related to affinity of the binding sites, $C_{\infty}$ Langmuir isotherm constant can be determined from the linearized form of [Eq. (18)]. The slope and intercept of the linear plot of $1 / C_{s}$ versus $1 / C_{a q}$ gave the values of $1 / C_{\infty}$ and $1 / K_{\mathrm{L}} C_{\infty}$, respectively. The theoretical maximum adsorption capacity $C_{\infty}$ corresponding to Langmuir constants is numerically equal to $1 / C_{\infty}$. As illustrated in Figure 12, the maximum adsorption capacity of CFA was reached when the equilibrium solution concentration was well below $1 \mathrm{mg} \mathrm{L}^{-1}$. This means that most of the equilibrium solution concentrations were quite low $\left(\ll 0.1 \mathrm{mg} \mathrm{L}^{-1}\right.$ ). As a result of scattering low $C_{a q}$ data, the Langmuir equation was best used to provide an indication of the equilibrium adsorption capacities, rather than the prediction of $C_{s}$, when it is less than the equilibrium value, even though the $R^{2}$ values are high.

In order to know the feasibility of the isotherm, the essential features of Langmuir model can be expressed in terms of separation factor or equilibrium parameter $R_{\mathrm{L}}$ which was defined by:

$$
\begin{aligned}
& R_{L}=\frac{1}{1+a_{L} C_{a q}} \\
& a_{L}=\frac{K_{L}}{C_{\infty}} \\
& R_{L}=\frac{1}{1+\frac{K_{L}}{C_{\infty}} C_{a q}}
\end{aligned}
$$

The values of $R_{L}$ indicate the shapes of isotherms to be either unfavorable $\left(R_{\mathrm{L}}>1\right)$, linear $\left(R_{\mathrm{L}}=1\right)$, favorable $(0<$ $\left.R_{\mathrm{L}}<1\right)$ or irreversible $\left(R_{\mathrm{L}}=0\right)$. The $R_{\mathrm{L}}$ values for $\mathrm{Cu}(\mathrm{II})$ and $\mathrm{Zn}(\mathrm{II})$ were calculated and plotted against the initial metal ion concentration. Figure 13 shows that, the sorption of $\mathrm{Cu}(\mathrm{II})$ on CFA increased as the initial metal ion concentration increased from 10 to $500 \mathrm{mg} / \mathrm{L}$, indicating that adsorption is even favorable for the higher metal ion concentrations that have been investigated. The $R_{\mathrm{L}}$ values

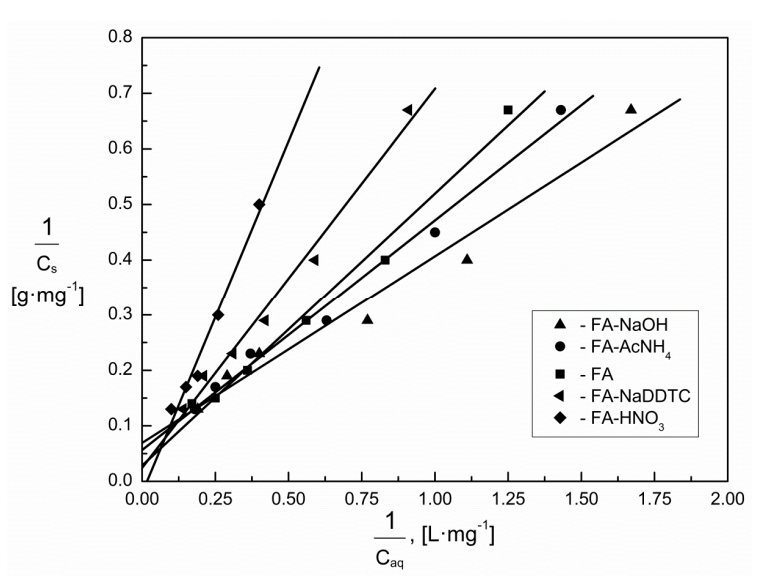

Figure 12. Langmuir isotherm plot for the adsorption of $\mathrm{CU}(\mathrm{II})$ ions onto primary FA and chemically-modified FA.

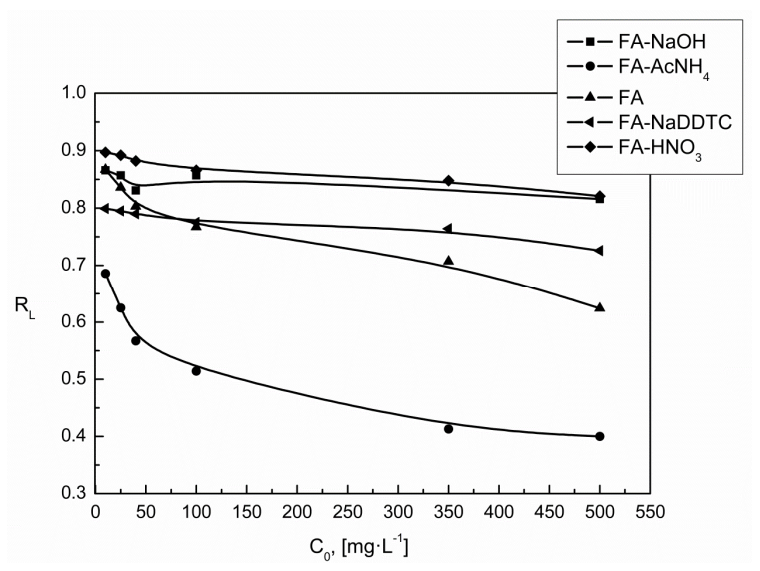

Figure 13. The calculated separation factor profile for $\mathrm{Cu}(\mathrm{II})$ ion as a function of initial metal ion concentration.

for $\mathrm{Cu}$ (II) were in the range 0.983 to 0.796 for the initial concentration of the metal ions $(10-500 \mathrm{mg} / \mathrm{L})$. This parameter $\left(0<R_{\mathrm{L}}<1\right)$ indicated that the CFA is a suitable adsorbent for the adsorption of $\mathrm{Cu}(\mathrm{II})$ and $\mathrm{Zn}(\mathrm{II})$ ions from aqueous solutions. 


\section{FREUNDLICH ISOTHERM MODEL}

The Freundlich isotherm is an empirical equation employed to describe heterogeneous systems. The Freundlich equation (22) is expressed:

$$
C_{s}=K_{F} \cdot\left(C_{\infty}\right)^{1 / n}
$$

The Freundlich equation predicts that the metal ion concentration on the sorbent will increase as long as there is an increase in the metal ion concentration while experimental results showed a plateau indicating a limiting value of the sorption.

The logarithmic form of the Freundlich model is given by the following equation:

$$
\log C_{s}=\frac{1}{n} \log C_{a q}+\log K_{F}
$$

where $K_{F}$ and $n$ are characteristic constants representing the adsorption capacity and adsorption intensity of the system respectively. The linear plot between $\log C_{s}$ versus log$C_{a q}$ (Figure 14) gives a slope which is equal to the value of $1 / n$ and the intercept is $\log K_{F}$. The magnitude of $1 / n<1$ $(n>1)$ indicates the favorability of the process of adsorption.

The increase in the maximum adsorption capacity of the modified CFA, with an increase in the solution temperature, together with the shape of the isotherms described earlier, indicates that the adsorption of heavy metals by the chemically-modified CFA most likely occurs through chemical rather than physical interactions. In order to gain a better understanding of the adsorption mechanism, all isotherms were fitted by the Langmuir model.

The Langmuir and Freundlich parameters calculated from the slope and intercept of the plots are presented in Table 3.

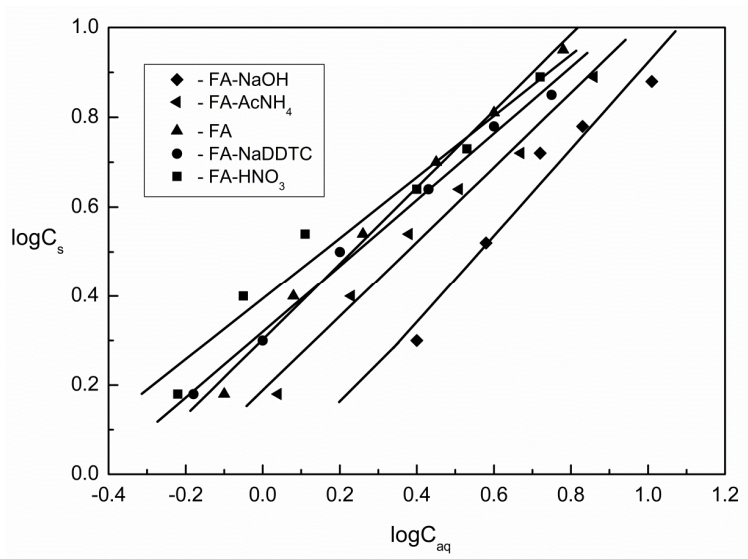

Figure 14. Freundlich isotherm plot for the adsorption of $\mathrm{Cu}(\mathrm{II})$ ion onto primary CFA and chemically-modified CFA.
From the data it was concluded that the experimental values fitted well into Langmuir isotherm model with high regression coefficients compared to Freundlich isotherm model, there by indicating the monolayer adsorption of $\mathrm{Cu}(\mathrm{II})$ and $\mathrm{Zn}(\mathrm{II})$ ions onto CFA.

BRUNAUER, EMMETT AND TELLER ISOTHERM MODEL Researched multilayer adsorption on the basis of BET isotherm. The results obtained on the adsorption of $\mathrm{Cu}(\mathrm{II})$ and $\mathrm{Zn}(\mathrm{II})$ ions were analyzed by the well-known models given by Brunauer, Emmett and Teller (Figure 15).

\section{Selectivity of CFA/modified-CFA To- wards Metal Ions}

The adsorption parameters obtained from both the models were given in Table 3. The experimental data were fitted well with Langmuir isotherm suggesting that the metal ions

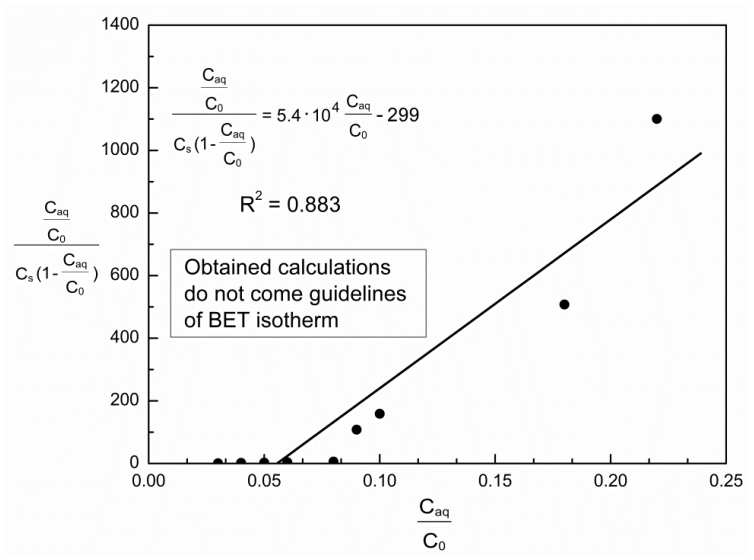

Figure 15. BET isotherm plot for the adsorption of $\mathrm{Cu}(\mathrm{II})$ ion onto CFA- $\mathrm{NaOH}$.

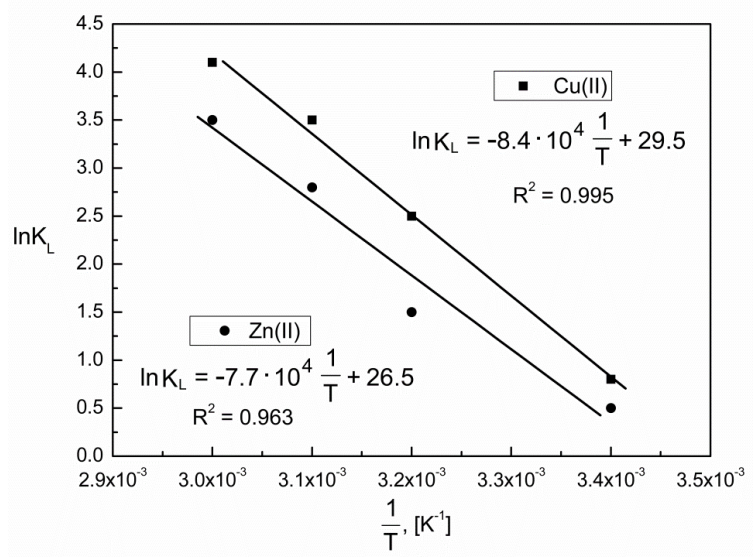

Figure 16. Arrhenius plot for the adsorption of $\mathrm{Cu}(\mathrm{II})$ and $\mathrm{Zn}(\mathrm{II})$ ions by $\mathrm{CFA}-\mathrm{NaOH}$. 
Table 4. The characteristic parameters of adsorption process of $\mathrm{Cu}(\mathrm{II})$ and $\mathrm{Zn}(\mathrm{II})$ ions on $\mathrm{NaOH}-\mathrm{FA}$.

\begin{tabular}{|c|c|c|c|c|c|c|c|c|c|c|c|}
\hline \multirow{2}{*}{ Ion } & \multirow{2}{*}{$T / \mathrm{K}$} & \multicolumn{3}{|c|}{ Langmuir constants } & \multicolumn{4}{|c|}{ Freundlich constants } & \multirow{2}{*}{$\begin{array}{c}\Delta G^{\circ} / \\
\mathrm{kJ} \mathrm{mol}^{-1}\end{array}$} & \multirow{2}{*}{$\begin{array}{c}\Delta H^{\circ} / \\
\mathrm{kJ} \mathrm{mol}^{-1}\end{array}$} & \multirow{2}{*}{$\begin{array}{c}\Delta S^{\circ} / \\
\mathrm{J} \mathrm{K}^{-1} \mathrm{~mol}^{-1}\end{array}$} \\
\hline & & $\begin{array}{c}\mathrm{C}_{\infty} / \\
\mathrm{mg} \mathrm{g}^{-1}\end{array}$ & $\begin{array}{c}K_{\mathrm{L}} / \\
\mathrm{L} \mathrm{mg}^{-1} \\
\end{array}$ & $R^{2}$ & $1 / n$ & $n$ & $\begin{array}{l}K_{\mathrm{F}} / \\
\mathrm{Lg}^{-1}\end{array}$ & $R^{2}$ & & & \\
\hline \multirow{4}{*}{$\mathrm{Cu}(\mathrm{II})$} & 293 & 15.2 & 0.002 & 0.995 & 0.90 & 1.11 & 7.36 & 0.936 & -1.95 & \multirow[t]{4}{*}{67.64} & \multirow[t]{4}{*}{237.50} \\
\hline & 308 & 21.9 & 0.012 & 0.998 & 1.23 & 0.81 & 10.17 & 0.926 & -6.40 & & \\
\hline & 318 & 54.1 & 0.033 & 0.988 & 1.25 & 0.80 & 12.28 & 0.946 & -9.11 & & \\
\hline & 333 & 75.4 & 0.060 & 0.989 & 0.87 & 1.15 & 19.16 & 0.967 & -11.35 & & \\
\hline \multirow{4}{*}{$\mathrm{Zn}(\mathrm{II})$} & 293 & 4.5 & 0.001 & 0.975 & 1.18 & 0.84 & 6.29 & 0.912 & -1.22 & \multirow[t]{4}{*}{61.46} & \multirow[t]{4}{*}{213.93} \\
\hline & 308 & 19.2 & 0.004 & 0.999 & 0.98 & 1.02 & 8.14 & 0.985 & -3.84 & & \\
\hline & 318 & 42.3 & 0.015 & 0.994 & 0.96 & 1.04 & 12.51 & 0.935 & -7.27 & & \\
\hline & 333 & 56.8 & 0.029 & 0997 & 0.87 & 1.15 & 16.46 & 0.907 & -9.69 & & \\
\hline
\end{tabular}

sorbed from monolayer coverage on the adsorbent surface. To lesser extent, the equilibrium data were also well described with the Freundlich model, probably due to the real heterogeneous nature of the surface sites involved in the process of adsorption. The correlation coefficient $\left(R^{2}\right)$ value found to be nearly equal to 0.95 indicates that both the models can be used to describe the adsorption process. The $1 / n$ values were between 0 and 1 indicating that the adsorption of $\mathrm{Cu}$ (II) and $\mathrm{Zn}$ (II) onto CFA/modified-CFA was favorable at the studied conditions.

The adsorption capacity of CFA/modified-CFA towards the studied metal ions is found to be in the order $\mathrm{Cu}(\mathrm{II})>\mathrm{Zn}(\mathrm{II})$. The selectivity sequence of metal is generally explained on the basis of properties of metal ions such as ionic radii, atomic weight, softness, electronegativity and hydrolysis constants of metal cations. This selectivity sequence may be explained on the basis of first hydrolysis constant values of these metal ions. The hydrolyzed metal ion $\left(\mathrm{MOH}^{+}\right)$is strongly sorbed than free metal cations. This can be attributed to the fact that, when the metal ions present in the solution, may diffuses to the surface sites slowly or rapidly, however, diffusion might be retarded when the metal ions are hydrated. The preferential uptake of $\mathrm{Cu}$ (II) ions by CFA is assigned to its lowest $\mathrm{pH}$ of hydrolysis. The uptake of $\mathrm{Cu}$ (II) ions is less compared to $\mathrm{Cu}$ (II) ions because of its higher $\mathrm{pH}$ values at which $\mathrm{Zn}$ (II) ion hydrolysis begins to occur. It could be explained by considering the hydrated ionic radii of cations; $\mathrm{Cu}^{2+}(4.19 \AA)$ and $\mathrm{Zn}^{2+}(4.30 \AA)$.

Since $\mathrm{Cu}(\mathrm{II})$ ions have the smallest hydrated ionic radii, it is possible that with fewer weakly bonded water molecules they tend to move faster to the potential adsorption sites on CFA/modified-CFA, when compared to the cations with higher hydrated ionic radii. The observed trend could also be accounted by considering the electronegativity also. The electronegativity of these ions can also play a role on the selectivity of adsorbent towards different heavy metal ions. Since $\mathrm{Cu}(\mathrm{II})$ has got the highest electronegativity (1.9), it's tendency to react with the potential adsorption sites is more compared to the other metal ions studied.

\section{Thermodynamic of Heavy Metal Ions Adsorption}

The adsorption of metal ions were studied at 4 different temperatures in the range 293 to $333 \mathrm{~K}$ using CFA as an adsorbent and the metal ion concentration of $50 \mathrm{mg} \mathrm{L}^{-1}$. The experimental result showed that the adsorption capacity decreases with decrease in the solution temperature. The decrease in the rate of adsorption with the decrease in temperature may be attributed to the weakening of adsorptive forces between the active sites of the adsorbents and adsorbate species and also between the adjacent molecules of the adsorbed phases. The variation in the extent of adsorption with respect to temperature has been explained on the basis of thermodynamic parameters, like change in enthalpy $\Delta H^{\circ}$, change in entropy $\Delta S^{\circ}$ and change in Gibb's free energy $\Delta G^{\circ}$, were determined using the following equations (24), (25) and (26):

$$
\begin{aligned}
& \Delta G^{\circ}=-R T \ln K_{L} \\
& \Delta H^{\circ}=E_{A}-R T \\
& \Delta S^{\circ}=\frac{\Delta H^{\circ}-\Delta G^{\circ}}{T}
\end{aligned}
$$

where $K_{L}$ is the equilibrium constant in the Langmuir isotherm, $R$ is the gas law constant and $T$ is the absolute temperature.

Activation energy $E_{\mathrm{a}}$ can be calculated using the equation (28) from the slope and intercept of the Arrhenius plot of $\ln K_{\mathrm{L}}$ versus $1 / T$ (Figure 16).

$$
K_{\mathrm{L}}=A \cdot e^{-\frac{E_{a}}{R T}}
$$




$$
\ln K_{\mathrm{L}}=-\frac{E_{a}}{R} \cdot \frac{1}{T}+C
$$

Determination of $E_{a}$ for $\mathrm{CU}(\mathrm{II})$ and $\mathrm{Zn}(\mathrm{II})$ ions was calculated to be 70.1 and $63.9 \mathrm{~kJ} \mathrm{~mol}^{-1}$, respectively.

The standard free energy change, $\Delta G^{\circ}$ reflects the feasibility of the process and standard entropy change $\Delta S^{\circ}$ determines the disorderliness of the adsorption at solidliquid interface. The values of $\Delta H^{\circ}$ and $\Delta S^{\circ}$ were calculated from the equation are given as $67.64 \mathrm{~kJ} \mathrm{~mol}^{-1}$ and 237.50 $\mathrm{J} \mathrm{K}^{-1} \mathrm{~mol}^{-1}$ for $\mathrm{Cu}(\mathrm{II})$ ion, respectively and $61.46 \mathrm{~kJ} \mathrm{~mol}^{-1}$ and $213.93 \mathrm{~J} \mathrm{~K}^{-1} \mathrm{~mol}^{-1}$ for $\mathrm{Zn}(\mathrm{II})$ ion, respectively. The results are shown in Table 4.

The positive values of standard enthalpy change $\Delta H^{\circ}$ for the intervals of temperatures showed the endothermic nature of the adsorption process. The estimated values of $\Delta H^{\circ}$ for the present system were greater than $20 \mathrm{~kJ} \mathrm{~mol}^{-1}$ and hence, the process may involve a spontaneous sorption mechanism as ion exchange where chemical bonds are not of strong energies. The positive value of $\Delta S^{\circ}$ suggests that the process of adsorption is spontaneous and thermodynamically favorable. The values of $\Delta G^{\circ}<0 \mathrm{~kJ} \mathrm{~mol}^{-1}$ indicate the spontaneous nature of the process.

\section{CONCLUSION}

The chemical treatment of adsorbents has been shown here to have significant effects on the adsorption capacity of coal fly ash on heavy metals as zinc and copper. Results showed that the $\mathrm{NaOH}$-treated fly ash (CFA- $\mathrm{NaOH}$ ) is a highly effective adsorbent than the $\mathrm{HNO}_{3}$-treated fly ash $\left(\mathrm{CFA}-\mathrm{HNO}_{3}\right.$ ) and untreated fly ash (CFA). Synthetic zeolite was obtained at laboratory scale during hydrothermal synthesis of fly ash with $\mathrm{NaOH}$ solution. Improvement of the textural properties and percentage of adsorption indicates the possibility of the derived zeolite material application as adsorbent for removal heavy metal ions from water and wastewaters.

The $\mathrm{pH}$ of the solution, initial metal ion concentration, time and temperature are found to play a crucial role in the process of adsorption of $\mathrm{CU}$ (II) and $\mathrm{Zn}(\mathrm{II})$ ions onto the CFA/modified-CFA. The adsorption capacity and kinetics for the adsorbents investigated were well described by the monolayer adsorption model of the Langmuir isotherm and the chemisorption model of pseudo-second-order kinetics. The maximum monolayer adsorption capacity of the CFA- $\mathrm{NaOH}$ was unaffected at $333 \mathrm{~K}, 2$ hours and $\mathrm{pH}=9$, but decreased at lower $\mathrm{pHs}$, and were found to be 75.4 and 56.8 $\mathrm{mg} \mathrm{g}^{-1}$ for $\mathrm{Cu}(\mathrm{II})$ and $\mathrm{Zn}$ (II) ions respectively. Intra-particle diffusion model suggested that the initial adsorption rate controlled by the film diffusion, which followed by the pore diffusion or external mass transfer effects. The thermodynamic calculations suggested (heat of adsorption $-\Delta H^{\circ}$ ) that the adsorption of $\mathrm{Cu}(\mathrm{II})$ and $\mathrm{Zn}(\mathrm{II})$ ions onto $\mathrm{NaOH}-\mathrm{CFA}$ is an endothermic nature of the process and low values of free energy $\left(\Delta G^{\circ}\right)$ indicated the spontaneity of the process. Equilibrium experiments shows that the selectivity of CFA and CFA-NaOH towards $\mathrm{Cu}(\mathrm{II})$ ions is more than that of $\mathrm{Zn}(\mathrm{II})$ ions, which is related to their hydrated ionic radius and first hydrolysis equilibrium constant. The competitive adsorption experiment indicated that CFA and CFA- $\mathrm{NaOH}$ had a stronger affinity to $\mathrm{Cu}$ (II) than to $\mathrm{Zn}$ (II) ion. We propose that the chemical enhancement of coal fly ash by alkali treatment yields an effective and economically feasible material for the treatment of heavy metal-containing effluents.

Acknowledgment. The authors are grateful to the Laboratory of Spectrometry and Laboratory of Scanning Microscopy for providing the laboratory support and facilities.

X-ray analysis was made in the Laboratory of Spectrometry, Faculty of Chemistry, Rzeszów University of Technology, 6 Powstanców Warszawy Ave., 35-959 Rzeszów, Poland and was financed from DS budget.

SEM-EDS analysis was made in the Laboratory of Scanning Microscopy, Faculty of Mechanical Engineering and Aeronautics, Department of Casting and Welding, Rzeszów University of Technology, 6 Powstanców Warszawy Ave., 35-959 Rzeszów, Poland.

\section{REFERENCES}

[1] Statistical yearbook 2010. Condition and environmental protection, Warsaw (Poland), 2010.

[2] M. Ahmaruzzaman, Prog. Energ. Combust. 2010, 36, 327.

[3] F. Canpolat, K. Yilmaz, M. M. Kose, M. Sumer, M. A. Yurdusev, Cement Concrete Res. 2004, 34, 731.

[4] E. Sočo, J. Kalembkiewicz, J. Hazard. Mater. 2007, $145,482$.

[5] F. Jiao, N. Wijaya, L. Zhang, and Y. Ninomiya, R. Hocking, Environ. Sci. Technol. 2001, 45, 6640.

[6] V. V. Seredin, R. B. Finkelman, Int. J. Coal Geol. 2008, 76, 253.

[7] W. Berg, H. J. Feuerborn, Coal combustion products in Europe trends and developments, in: Proceedings of World of Coal Ash Conference. University of Kentucky, Lexington, 2007.

[8] O. E. Manz, Fuel 1997, 76, 691.

[9] L. Ruhl, A. Vengosh, G. S. Dwyer, H. Hsu-Kim, A. Deonarine, Environ. Sci. Technol. 2010, 44, 9272.

[10] C. An, G. Huang. Environ. Sci. Technol. 2012, 46, 12742.

[11] A. Derkowski, W. Franus, E. Beran, A. Czímerová, Powder Technol. 2006, 166, 47.

[12] A. Derkowski, W. Franus, H. Waniak-Nowicka, A. Czímerová, Int. J. Miner. Process. 2007, 82, 57. 
[13] M. Nascimento, P. S. Moreira Soares, V. P. de Souza, Fuel 2009, 88, 1714.

[14] R. Juan, S. Hernandez, X. Querol, J. M. Andres, N. Moreno, J. Chem. Technol. Biot. 2002, 77, 299.

[15] A. Moutsatsou, E. Stamatakis, K. Hatzizotzia, V. Protonotarios, Fuel 2006, 85, 657.

[16] P. R. Penilla, A. G. Bustos, S. G. Elizalde, Fuel 2006, 85, 823.

[17] X. Queroll, N. Moreno, J. C. Umana, A. Alastuey, E. Hernandez, A. Lopez-Soler, F. Plana, Int. J. Coal Geol. 2002, 50, 413.

[18] H. Tanaka, Y. Sakai, R. Hino, Mater. Res. Bull. 2002, 37, 1873.

[19] K. Bedoui, I. Abbes Bekri, E. Srasra, Desalination 2008, 223, 269.

[20] R. Chitrakar, S. Tezuka, A. Sonoda, K. Sakane, K. Ooi, T. Hirotsu, J. Colloid Interface Sci. 2005, 290, 45.

[21] T. R. Ferreiraa, C. B. Lopesb, P. F. Litoa, M. Oterob, Z. Lina, J. Rochaa, E. Pereirab, C. M. Silvaa, A. Duarteb, Chem. Eng. J. 2009, 147, 173.

[22] M. Jiang, X. Jin, X. Lu, Z. Chen, Desalination 2010, 252, 33.
[23] G. Rangel-Porras, J. B. Garcia-Magno, M. P. Gonzalez-Munoz, Desalination 2010, 262, 1.

[24] S. M.Maliyekkal, Anshup, K. R. Antony, T. Pradeep, Sci. Total Environ. 2010, 408, 2273.

[25] D. H. K. Reddya, K. Seshaiaha, A. V. R. Reddy, M. Madhava Rao, M. C. Wang, J. Hazard. Mater. 2010, $174,831$.

[26] L. Zhenga, Z. Danga, X. Yi, H. Zhanga, J. Hazard. Mater. 2010, 176, 650.

[27] S. Debnath, U. C. Ghosh, Chem. Eng. J. 2009, 152, 480.

[28] E. Pehlivan, S. Cetin, B.H. Yank, J. Hazard. Mater. 2006, 135, 193.

[29] Z. Sarbak, M. Kramer-Wachowiak, Powder Technol. 2002, 123, 53.

[30] N. Kantiranis, A. Filippidis, T. Mouhtaris, K. M. Paraskevopoulos, T. Zorba, C. Squires, D. Charistos, Fuel 2006, 85, 360.

[31] S. J. Allen, G. Mckay and K. Y. Khader, Environ. Pollut. 1989, 50, 39.

[32] S. H. Chien, and W. R. Clayton, Soil Sci. Soc. Am. J. 1980, 44, 265. 